\title{
Dubin-Johnson syndrome
}

INSERM

\section{Source}

INSERM. (1999). Orphanet: an online rare disease and orphan drug data base. DubinJohnson syndrome. ORPHA:234

Dubin-Johnson syndrome (DJS) is a benign, inherited liver disorder characterized clinically by chronic, predominantly conjug ated, hyperbilirubinemia and histopathologically by black-brown pigment deposition in parenchymal liver cells. 